Peter Madsen

\title{
Historie og bevidsthedshistorie
}

Om uensartethed og ideologisk hegemoni-

også et bidrag til kritik af ånden fra Frankfurt

\section{TOTALITETSBETRAGTNINGEN}

Diskussionerne om »bevidsthedshistorie « har i Danmark i vidt omfang været inspireret af de forskellige stadier i frankfurterskolens udvikling fra Horkheimer og Adorno over Habermas til Negt. Det er derfor nærliggende at tage udgangspunktet $i$ denne tradition, hvorigennem også træk, der ikke direkte hidrører derfra, kan karakteriseres. Hovedlinjen i det følgende er en kritik af spekulativ historieskrivning, men vejene til konkretisering af den historiske analyse er krogede, opgaven består ikke $\mathrm{i}$ blot at hengive sig til den mangfoldige empiri. Selv om abstrakte begrebsdannelser kan være blokerende for den konkrete analyse, hvis de absoluteres til forudgivet sandhed, der udtømmer emnet, så er på den anden side en vis begrebsmæssig anstrengelse, som Adorno ville sige det, en forudsætning for analyse.

Historieperspektivet i Horkheimers og Adornos Oplysningens dialektik er-som titlen angiver det-centreret omkring dobbeltheden i den oplyste menneskeheds fremskridt og særlig dobbeltheden i oplysningstænkningen. Forud for udviklingen af den moderne histories beherskelse af naturen gik epoker, der fundamentalt var præget af naturtvang og hertil svarende mytisk tænkning. Med den voksende naturbeherskelse skete også en nedbrydning af den mytiske tænkning, formidlet igennem den rationelle kritik. Udviklingen havde for så vidt karakter af en menneskenes frigørelses- 
proces, en bevægelse $i$ retning af myndighed. Men denne proces (hvis klassemæssige betingelser der her ses bort fra) medf $\varnothing$ rte samtidig i stigende grad en selvstændiggørelse af de samfundslovmæssigheder og svarende hertil en selvstændiggørelse af den rationelle tænkning, der forvandledes til instrumentel rationalitet. Naturtvangen afløstes af en samfundsmæssig tvang, og den mytiske bevidsthed af en underlæggelse under en fra den menneskelige frigørelsesbestræbelse løsrevet forstandskalkule, der på sin side i stigende grad blev underordnet den selvsamme tvangssammenhæng, som prægede samfundet. Hvor den oplyste tænkning førhen tjente frigørelsen igennem den fornuftige refleksion, dér tjener nu forstanden den kapitalistiske rationalitet, og i fornuftens sted træder da fornyede irrationelle myter til legitimering af herredømmet. I denne sidste henseende er det fascisme og nazisme, Horkheimer og Adorno har i tankerne, og det er denne irrationalitets rødder i forstandens løsrivelse fra fornuften, de s $\emptyset$ ger at spore i oplysningens dialektik. Men samtidig understreger de, hvordan der i selve den aktuelle samfundsform, kapitalismen, er anlagt en anden irrationalitet, tingsliggørelsen, som også Marx omtalte med reference til primitiv religion, nemlig som fetichisme, som en tillæggelse af selvstændige kræfter til tingene, da naturens, nu samfundets.

Et brud med hele denne djævelske tvangssammenhæng må derfor bevidsthedsmæssigt komme fra modsætningen til den instrumentelle fornuft og den moderne irrationalitet, de bevidsthedsmæssige sider af den samfundsmæssige tvangssammenhæng. Kilder til dette alternativ er den kritiske tanke og den kulturelle tradition, eller mere præcist: de i den kulturelle tradition opbevarede spor af den undertrykte og forrådte fornuft og menneskelige frihedsstræben. Disse er kilderne til opretholdelse af afstand til den samfundsmæssige tvang. Socialt set er alternativet forsvundet i og med proletariatets integration, dette sociale alternativ henviste Horkheimer til i trediverne som alliancepartner for den kritiske tænkning, men efter krigen var alternativet for forfatterne af Oplysningens dialektik ikke længere til stede på grund af fascismen, stalinismen og integrationsmekanismerne $\mathrm{i}$ de kapitalistiske samfund. Tilbage står altså intelligensiaens kritiske distance og 
sensibilitet for kulturarvens kritiske potentialer. Historien bliver således stiliseret $\mathrm{i}$ overvindelsen af naturtvangen og udviklingen af en samfundsmæssig tvang, og bevidsthedsmæssigt vil det sige overvindelsen af den af naturidolatri prægede mythos og samtidig udviklingen af en fetichistisk samfundsbevidsthed, tingligsgørelsens gennemtrængning af alle relationer og tankeformer. Ops $\varnothing \mathrm{g}-$ ningen af et alternativ må således orientere sig efter afstanden til tingsligg $\varnothing$ relsen. I mange henseender er dette historiesyn en den progressive borgerlige tænknings selvrefleksion, en indreborgerlig selvkritik, som af historiske grunde mistede det sociale klassetilknytningspunkt, nemlig proletariatet, som repræsenterede muligheden for løsrivelse fra den borgerlige horisont. Resultatet er en vision af samtiden som en stivnet tvangssammenhæng med tilsvarende bevidsthedsmæssig integration. Marcuse gav i Det éndimensionale menneske en klassisk fremstilling af dette samfundssyn, men da med en udvidelse af det kritiske potentiale til også at omfatte socialt marginaliserede grupperinger, unge, kvinder, etniske minoriteter. På den ene side er dette historiesyn så stiliseret, at den konkrete historie forsvinder til fordel for en abstrakt historiedialektik, men på den anden side rummer dette abstrakte billede også en del af sandheden, og først og fremmest er den kritiske brod imod de vitterlige træk af kapitalistisk dominans, socialt og bevidsthedsmæssigt, stærk og stadig aktuel.

Det er i hovedsagen det samme historiesyn, der ligger bag Habermas' Offentlighedens strukturforandring, som har spillet en større direkte rolle, formentlig bl. a. fordi den tilsyneladende er mere konkret. Perspektivet angår her »offentligheden $\ll$, kommunikationsformer og dertil knyttede opfattelser og idealer. Igen er udgangspunkt og slutpunkt delvist overensstemmende: fra den feudale repræsentative offentlighed til den moderne socialstats »refeudaliserede « offentlighed. Og ligesom hos Horkheimer og Adorno er det $\mathrm{i}$ h $\phi \mathbf{j}$ grad idealer fra den progressivt borgerlige epokes selvforståelse, der er styrende, dog - må det understreges - uden de to gamles radikale kritik af også de regressive elementer $i$ den progressive tænkning. For Horkheimer og Adorno var det magt- 
påliggende at udfri den kritiske utopi af den borgerlige tankegangs bornerte horisont, for Habermas træder kritikken i praksis i baggrunden og rettes i stedet imod den aktuelle situation (dette er naturligvis ikke ensbetydende med, at Habermas er blind for de to gamles pointer, det ligger ham imidlertid mere på sinde at fremføre idealet end at opretholde distancen). Derfor bliver historieforståelsen, trods den mere konkrete problemstilling, ideologisk. Den borgerlige offentlighed som idé bryder for Habermas historisk sammen p.g.a. ophævelsen af skellet mellem samfund og stat (samt p.g.a. organisationerne osv.), det skel som netop var betingelsen for en mellem samfund og stat formidlende offentlighed, men den grundlæggende årsag skal snarest søges deri, at en indløsning af det borgerlige ideal $\mathbf{i}$ og med proletariatets opkomst og vakst ville indebære magtpositioner til borgerskabets klassemæssige modstander. Ligesådan tilslører Habermas' stilisering af det historiske forløb de særlige tyske forhold, som er baggrunden for situationen $i$ efterkrigstidens Tyskland (men alt dette kan ikke uddybes her). Også hos Habermas ligger den kritiske modstand imod refeudaliseringen $\mathbf{i}$ den kritiske intelligensia, der repræsenterer potentialet for en genetablering af en borgerlig offentlighed på nye historiske præmisser, nemlig den historiske overvindelse af materiel mangel, dette ifølge Habermas.

Hvor Horkheimer og Adorno opretholdt en kritisk distanceret afstand imellem traditionens kritiske, utopiske momenter og dens borgerlige begrænsninger, der nærmer Habermas sig den aktuelle situation på bekostning af traditionens utopiske indhold, som reduceres til den kritiske intelligensias aktuelle progressive ideologi. Og netop denne tilsyneladende tilnærmelse til virkeligheden er ensbetydende med et fravær af historisk konkretion. Hvilket dog naturligvis ikke betyder en total virkelighedsfjernhed, men netop rejser problemet om samtidsforankring.

Med Negt \& Kluges Offentlighed og erfaring, som ikke tilfældigt er tilegnet Adorno, er den aktuelle udfordring søgt taget op - på baggrund af de to gamles og Habermas' arbejde. Grundlæggende ud fra den tanke, at den aktuelle indløsning af de utopisk-kritiske 
elementer $\mathrm{i}$ den progressive borgerlige tradition må være proletariatets sag. Ikke forstået plat som at spørgsmål om at sætte klasseinteresse over for klasseinteresse, men forstået således, at proletariatet samfundsmæssigt set er den klasse, som igennem sin placering i netop den samfundsmæssiggjorte produktion repræsenterer et potentielt alternativ til mangfoldigheden af isolerede borgerlige subjekter og dermed også til den borgerlige politikform, der netop forudsætter samfundsborgernes indbyrdes isolering. Der ligger heri et tilløb til overvindelse af den horisontbegrænsning, som på hver sin måde præger Horkheimer/Adorno og Habermas. Men $i$ alt for h $\phi j$ grad forbliver perspektivet - og særlig den danske brug af bogen - inden for rammerne af spillet mellem de store, almene historiske perspektiver og de almene civilisationstrak aktuelt.

Fælles for disse tre syn på historien og bevidsthedshistorien er så at sige deres på én gang spekulative og abstrakte karakter. Ikke sådan at de skyr den umiddelbare virkelighed, men sådan at den konkrete historie kun træder ind, når den elementvis lader sig indordne i de abstrakte historiefilosofiske temaer. For så vidt kan de siges at ligge inden for den refleksionsramme, som blev anlagt med Lukács' Historie og klassebevidsthed, dvs. inden for en marxistisk tradition, eller marxistisk inspireret tradition, der på den ene side repræsenterer et progressivt modstykke til 2. og 3 . internationales forfaldne marxisme, men som på den anden side deler den systembyggende klassiske filosofiske traditions spekulative præg. Det afgørende problem består derfor i at præcisere den abstrakte analyses stilling $\mathrm{i}$ den konkrete historieanalyse.

\section{UENSARTETHEDEN}

Den nyere tids historie er nok i stigende grad kapitalens historie, men med kapitalens historie er den nyere tids historie ikke udtømt. Kapitalens historie i selv selv indbefatter endvidere ikke blot de værdimæssige bevægelser, uden konkret socialt og menneskeligt indhold kan heller ikke de kapitalistiske former reproduceres og udvikles, og dette sociale og menneskelige indhold kan hver- 
ken begrebsmæssigt eller reelt opsuges af kapitalen. Kan man således udfri sin analyse af den empiristiske nedsunkethed $i$ realiteternes mangfoldighed igennem den marxistiske kapitalanalyses kategorier, så løber man til gengæld en alvorlig risiko for i fascinationen af det intellektuelt tilfredsstillende system at tabe blikket for den reelle kompleksitet. Risikoen er at de analytiske kategorier ikke blot løfter analytikeren op over empirien og dermed overhovedet gør analyse mulig, men at analytikeren ydermere taber empirien af sigte og lader systemet gøre det ud for analyse.

En forankring af bevidsthedsanalysen socialt kan gă igennem begrebet om karaktermasker. Dette begreb peger hos Marx på den adfærd, som er nødvendig i ganske bestemte sociale sammenhæng, eksemplarisk er forholdet fremstillet i Brechts Det gode menneske fra Sezuan, hvor hovedpersonen gang på gang må foretage sig ting, hun ikke bryder sig om, fordi hun erhverver sit eksistensgrundlag og grundlaget for sin menneskelige godgørenhed igennem kapitalistisk virksomhed. Det gode menneske må fordoble sig og træde op som sin fætter, som hele tiden gør det rigtige - set ud fra den $\emptyset$ konomiske rationalitets synsvinkel. I det omfang en sådan karaktermaske giver sig bevidsthedsmæssigt udslag bliver resultatet en ganske bestemt opfattelse af den sociale sammenhæng og af sig selv. Det er det Marx kalder ideologi og sætter i modsætning til begrebsmæssig analyse. Der ligger her et alternativ til den ideologiforståelse, der forestiller sig ideologier som tilsløringsstrategier ud fra beherskelsesinteresser (indoktrinering), og alternativet er - kan man sige - historisk materialistisk. Det ligger på denne baggrund lige for at studere bevidsthedshistorien som de til de forskellige karaktermasker knyttede ideologiers historie, men dette projekt vil være en misforståelse af begrebet status - og i øvrigt nok så vigtigt: det vil ikke have mulighed for at analysere den virkelige historie, kun bestemte aspekter. Ligesom det gode menneske i Sezuan er alle historiens individuelle personer noget andet end blotte bærere af karaktermasker. Hvad begrebet kan fastholde, det er den sociale tvang til bestemte handlinger og de bevidsthedsmæssige mønstre, som disse handlinger 
og denne tvang giver grundlag for. Men dette er kun ét - omend vigtigt - moment $\mathrm{i}$ det individuelle, gruppe- og klassemæssige bevidsthedsliv, ligesom i $\emptyset$ vrigt det tvangsstyrede kun er ét - også dette vigtigt - moment $\mathrm{i}$ den sociale og individuelle situation og aktivitet. Sat på formel kan forholdet udtrykkes som samspillet mellem karaktermaske og subjekt, erfaringsdannelsens betingelsessammenhæng er mere kompleks end de фkonomiske tvangsforhold (det er ikke muligt her at gå ind på forskelle imellem førkapitalistiske og kapitalistiske udgaver af denne problematik).

Er der således på - så at sige - individsiden ganske bestemte grænser for kapitalanalysens rækkevidde, så er der det ligesådan på den sociale side, for så vidt som de kapitalistiske økonomisksociale relationer for det første ikke - som nævnt - opsuger deres realgrundlag i sig og for det andet heller ikke på det $\emptyset$ konomisksociale niveau selv er enerådende. Til det sidste kan bemærkes, at den småborgerlige samfundsplacering kun indirekte - men til gengæld stærkt, bør det tilføjes - styres af kapitalistiske relationer, selv om denne placering naturligvis styres af varerelationer. Det førstnævnte, nemlig at realgrundlaget ikke opsuges af kapitalen, er en måske kryptisk formulering af et meget enkelt og indlysende forhold, her blot formuleret så at sige ud fra kapitalanalysens synsvinkel. En vare er ikke blot bærer af værdi, den har også en bestemt konkret brugsværdi, en genstandskarakter, som nok er præget af dens baggrund i produktionsprocessen, men immervak forbliver en del af en sanselig konkret verden. Drives skovbrug kapitalistisk, så forhindrer det ikke træernes naturlige karakter $\mathbf{i}$ at udfolde sig, og det forhindrer heller ikke menneskers sanselige forholden sig til - eller $\mathbf{i}$ - denne skov. Dette gælder også socialt. På den ene side kan man meget vel fremhæve, at den kapitalistiske udvikling på mange måder tenderer imod at udslette historien, eller altså sporene af den historiske fortid, men på den anden side har også dette sine grænser (som vel at mærke endnu ikke er nået): den socialt-kulturelle virkelighed i kapitalistiske samfund er grundlæggende præget af en mangfoldighed og forskelligartethed, som bærer sporene af fortiden. Og denne for- 
tid er forskellig fra land til land, fra lokalitet til lokalitet. Dette gælder på alle niveauer. Men det er på sin side ikke ensbetydende med et fravær af systematiske særtræk, som f.eks. den småborgerlige sektors store betydning i Danmark eller de mange revolutioners politiske betydning i Frankrig. Den historiske analyses opgave bliver derfor at opspore ikke blot de overordnede $\emptyset$ konomisksociale bestemmelser, men også den фkonomisk-sociale kompleksitet. Og den bevidsthedshistoriske analyses opgave bliver tilsvarende ikke blot at opspore de grundlæggende ideologiske tilskyndelser (forholdet karaktermaske-ideologi, med de anvendte termer), men også mangfoldigheden i livssituationen og den historiske baggrund samt deraf udspringende bevidsthedsmæssige forhold.

I denne kompleksitet, som er det virkelige forskningsemnes, ligger omfattende brydninger, uensartetheden er konfliktfyldt, og så meget desto mere må bevidsthedshistorien sigte imod at fremdrage disse brudflader og forholdet mellem disse og de overordnede styringer. I samme grad denne kompleksitet undertrykkes i forskningen bidrager denne forskning til blokeringen af sit publikums selvrefleksion og samtidserkendelse og modvirker således den impuls til frigørelse, som skulle være forskningens hensigt. Så meget mere i litteraturforskningen som de litterære værker er eller rettere kan være - vidnesbyd om kompleksiteten i liv og erfaring. At fremhæve denne kompleksitet er ikke et oplæg til dyrkelse af den som sådan og derigennem afsværgning af analyse af de overordnede sammenhæng, som også er en realitet, og oftest en realitet af repressiv art. Men netop imod denne overordnede sammenhæng brydes såvel erindring om det anderledes, som erfaringer dermed $i$ samtiden og forhåbninger om en anderledes fremtid født af samtidens uensartethed.

Ernst Bloch har på flere niveauer ført en polemik imod tendenser i retning af erkendelsesmæssig underordning af realiteterne og ikke mindst bevidsthedslivet under overordnede totalitetsbetragtninger. Hans polemik retter sig bl.a. imod Georg Lukács, såvel filosofisk-metodologisk (imod Historie og klassebevidsthed) som 
litteraturanalytisk. Dette sidste bl.a. i den såkaldte ekspressionismedebat $\mathrm{i}$ trediverne, hvorfra denne passage hidrører: $\gg$ Lukács forudsætter overalt en lukket sammenhængende virkelighed, tilmed en virkelighed, hvori f.eks. idealismens subjektive faktor ikke får nogen plads, men så meget mere den ubrudte stotalitet «, der er bedst udviklet $i$ idealistiske systemer og således også $\mathrm{i}$ den klassiske tyske filosofis systemer. Spørgsmålet er om det er en realitet; hvis det er det, er de ekspressionistiske fors $\emptyset \mathrm{g}$ på at nedbryde og interpollere, såvel som de nyere forsøg på indskud og montage ganske rigtigt tomt spilfægteri [i modsætning til den af Lukács fordrede realistiske gengivelse af den formidlede totalitet, ad modum Balzac - i Lukács' læsning/PM]. Men måske er Lukács' realitet, den uendeligt formidlede totalitetssammenhængs realitet, slet ikke så objektiv; måske indeholder selve Lukács' realitetsbegreb endnu klassisk-systemagtige træk; måske er den sande virkelighed også afbrydelse. Men eftersom Lukács har et objektivistisk-lukket realitetsbegreb, vender han sig i tilfældet med ekspressionismen mod ethvert kunstnerisk fors $\emptyset \mathrm{g}$ på at opløse et verdensbillede (også selvom verdensbilledet er kapitalismens). I en kunst, som udnytter de reale opløsninger af overfladesammenhængen og som fors $\emptyset$ ger at opdage nyt i hulrummene, ser han derfor i sig selv kun subjektivistisk opløsning; han sætter derfor eksperimentet med opløsning lig med tilstanden af forfald.« (»Diskussionen om ekspressionismen «, i Lukács: Essays om realisme bd. 1, 167-8, oversat fra Erbschaft dieser Zeit, hvor den principielle kritik af Lukács' tænkemåde og diskussion af usamtidighedsbegrebet findes s. 104 ff).

\section{HEGEMONI OG DE INTELLEKTUELLES ROLLE}

Til trods for uensartetheden og mangfoldigheden $i$ den sociale realitet og dermed også i de bevidsthedsmæssige forhold er der dog tale om en vis grad af konsensus $i$ de fleste samfund. Beror opretholdelsen af de herskende forhold ikke på ren magtudøvelse, så fordres der en vis ideologisk homogeneitet, en vis overensstemmelse i opfattelsen af forholdene, billedet af samfundet, betragtningen af den egne eksistens og fremtidsvisionerne. Denne rela- 
tive overensstemmelse, denne konsensus, er ikke ensbetydende med at den tidligere behandlede uensartethed ophæves, men derimod er der tale om en ideologisk figuration, der i sig kan indoptage også forskelligartede erfaringer. Det vil være fejlagtet at betragte den bevidsthedsmæssige overensstemmelse som udtryk for også fælles vilkår eller som udtryk for, at kun de træk i vilkårene, som er fælles, er udslagsgivende, når det gælder den side af det bevidsthedsmæssige, der peger $\mathrm{i}$ retning af det politiskideologiske niveau. Der går ingen lige vej fra ideologi i streng marxistisk forstand til ideologisk overensstemmelse $i$ den forstand, der her er tale om, heller ikke i samfund, der er grundlæggende præget af kapitalistiske produktionsforhold. Selv om der nok i de umiddelbare $\emptyset$ konomisk-sociale relationer ligger tilskyndelser til ideologiske former, der modsvarer de politiske former i parlamentariske demokratier, så er dette højst et grundlag for ideologiske integrationstiltag, ikke en tilstrækkelig betingelse, bl.a. fordi hele den omtalte uensartethed på de angivne forskellige niveauer gør sig galdende, men også fordi social erfaring ikke umiddelbart kan oversættes til politisk opfattelse. Selv om altså ideologi i streng forstand kan bestemmes som den til en karaktermaske svarende bevidsthedsform, så udtømmes ikke hermed alle de forhold, som behandles under betegnelsen ideologi, en streng puristisk holdning til dette terminologiske problem ville vanskeliggøre diskussion af de virkelige problemer, derfor er det på sin plads at behandle også spørgsmålet om politisk konsensus under betegnelsen ideologi.

$\gg$ Hvis politisk videnskab er ensbetydende med videnskab om Staten og staten er hele komplekset af praktiske og teoretiske aktiviteter, som den herskende klasse benytter ikke alene til at retfærdiggøre og opretholde sin dominans, men hvorigennem det også lykkes den at vinde de beherskedes konsensus, er det indlysende, at alle de væsentlige sociologiske spørgsmål ikke er andet end den politiske videnskabs spørgsmål « (Selections from the Prison Notebooks, s. 244).

Sådan formulerer Antonio Gramsci sit grundsynspunkt, og der- 
med er spørgsmålet om historie og bevidsthedshistorie stillet radikalt anderledes end $\mathbf{i}$ de former, det ovenfor har været diskuteret, omend Blochs perspektiv faktisk er det samme. Gramscis synsvinkel er bestemt ud fra interessen i for det første at analysere grundlaget for den italienske fascisme og for det andet at finde frem til grundlaget for et alternativ til fascismen (for hans vedkommende socialistisk revolution). Denne synsvinkel rummer en række frugtbare ansatser for et studium af bevidsthedshistorien, en historie, som ikke blot er social, men også politisk, ikke blot er bestemt af individernes, gruppernes og klassernes sociale eksistens, men også af de herskende politiske former og brydningerne mellem disse og historiske alternativer. Gramsci flytter så at sige synsvinklen fra samfundsborgerens til politikerens. Og set derfra er problemet som sagt at skabe og opretholde en loyalitet imod de herskende herredømmeforhold, en loyalitet som i mindst muligt omfang bygger på direkte tvang og i størst muligt omfang bygger på samtykke, på konsensus. Denne bestræbelse støder da imod netop den uensartethed, som har været diskuteret ovenfor, spørgsmålet om konsensus er et spørgsmål om at skabe en enhed på tværs af faktiske forskelle, og her rækker selv ikke den mest udviklede kapitalismes varerelationer til. Der må udvikles idealer, et fremtidsperspektiv, og alternative udviklingsperspektiver må diskrediteres. Det er denne opgave de intellektuelle varetager (når de da ikke bidrager til at udvikle netop alternativer - eller hengiver sig til blot nostalgi). Og denne opgave kan varetages på mange måder, selv nostalgi kan have sine samtidsfunktioner, som f.eks. romantisk national tilbageskuen som moment $i$ et nationalt borgerskabs konstitueringsproces. Der tilkommer da - i Gramscis optik - de intellektuelle en central rolle $\mathbf{i}$ bevidsthedshistorien, og det er da også netop de intellektuelle, der er det gængse emne for litteratur- og idehistorisk forskning. Hvad enten man bryder sig om det eller ej har netop de intellektuelle udformet de tankegange, som har forenet de klasser og grupper, der har været drivende $\mathrm{i}$ omvæltninger $\mathrm{i}$ historien, og de tankegange, der har holdt sammen, politisk-ideologisk, på samfundene i mere stabile (politisk set stabile) perioder, herunder perioder med krige. Og det 
er de intellektuelle, der har formidlet disse tankegange og forestillinger. I denne sammenhæng er det Gramsci anvender sit begreb om store intellektuelle, dvs. intellektuelle, som udformer nye tankeformationer, hans hovedeksempel er Benedetto Croce, men analyseformen kan anvendes mere generelt, eksempelvis kan man tænke på de kulturradikale tankegange, der i tresserne holdt sammen på den danske intelligensia i kritisk solidaritet med den socialdemokratisk prægede politiske konstellation. Her er det imidlertid ikke de konkrete eksempler, men de generelle tankegange, der er emnet. Den generelle pointe i Gramscis analyse af Croces intellektuelle funktion er, som det fremgår af hans artikel om det syditalienske spørgsmål, at det norditalienske borgerskab havde brug for en ideologisk formation, som kunne knytte også de syditalienske intellektuelle til det borgerlige projekt om et kapitalistisk forenet Italien, som havde sit udgangspunkt i Cavours samlingsstrategi ud fra det kapitalistisk mest avancerede Norditalien, politisk set først og fremmest Piemonte. Behovet for en samlende ideologi gav sig ud fra Italiens ekstremt ulige udvikling, som skarpt sat op kan karakteriseres som præget af på den ene side centraleuropæisk kapitalisme og på den anden side en uudviklethed af 3 . verdens-karakter i yderområderne, specielt »Syditalien «, dvs. halvøens sydlige dele og øerne (Gramsci kom modsætningsvis fra en af disse øer, nemlig Sardinien og havde i sin barndom og ungdom oplevet denne tilbageståenhed). Som Gramsci fremhæver havde de syditalienske intellektuelle $\mathrm{i}$ deres sociale funktion en personlig tilknytning til de fattige dele af befolkningen (f.eks. som lokaladministratorer) og kunne herudfra have udviklet en social alliance imod på den ene side godsejerne, som var borgerskabets allierede, på den anden side det norditalienske borgerskab, som havde karakter (og stadig i et vist omfang har det) af kolonisatorer (man kan sammenligne med danskernes rolle i Norge). Igennem Groces filosofi, historieskrivning og politiske aktivitet fik disse intellektuelle en orienteringsmulighed $i$ retning af den moderne liberale europæiske kultur (igen kan man sammenligne med den kulturradikale indoptagelse af den europæiske modernisme). På baggrund af deres faktiske tilknytning 
til de fattigere lag kunne så disse intellektuelle videreformidle denne ideologiske formation i realitetsnær form. Fusionen mellem den overordnede ideologi og den sociale erfaring var forudsætningen for ideologiens gennemslag (to sammenligninger i dansk sammenhæng: for det første højskolekulturens formidling mellem agrar erfaring og storbyintellektuel ideologi, grundtvigianismen, og modsætningsvis Hørups og den radikale del af venstres formidling mellem radikal storbyintelligensia og de fattigere agrare lag; og for det andet de socialdemokratiske tillidsmænd i fagbevægelsen, som formidler mellem arbejdererfaringerne og regeringspartiets orienteringshorisont).

De intellektuelle, som udøver disse funktioner deler Gramsci i to grupper, de organiske intellektuelle og de traditionelle intellektuelle. De organiske intellektuelle er dem en social formation udvikler fra sin egen erfaringshorisont. For det nyere borgerskabs vedkommende kan man tænke på kombinationen tekniker, forretningsmand og politiker, som ikke var sjælden i den tidligere kapitalisme (i Italien er Agnelli-familien det typiske eksempel fra Fiatfabrikkernes start og endnu i dag). For arbejderklassens vedkommende er det i Skandinavien typisk, at den socialdemokratiske bevægelse, særlig tidligere, hentede sine politikere fra arbejderklassen selv (Stauning f.eks. - eller Anker Jørgensen).

De traditionelle intellektuelle er de personer, der udøver allerede etablerede intellektuelle funktioner, men som gennem historien har skiftet klassemæssig orientering og i deres virke indoptaget nye erfaringshorisonter. For en opkommende klasse er det af afgørende betydning at disse traditionelle intellektuelle orienterer sig efter dennes interesser og perspektiver. Man kan tænke på præsterne i forrige århundrede (grundtvigianismen igen), på politterne $\mathrm{i}$ trediverne (som var rekrutteringsgruppe for socialdemokratiske intellektuelle) eller på lærere og socialarbejdere idag, som kampen står ganske hårdt om. På den ene side er der muligheden for en »statskapitalistisk « orientering (socialdemokratiet har fløje, der peger i denne retning), på den anden side er der muligheden for en orientering efter arbejderklassens langsigtede interesser om 
ikke arbejderklassens aktuelle politiske orientering (dette er naturligvis en omfattende problematik, som ikke er let at overskue på samme måde som tidligere epokers brydninger, men den er vigtig bl.a. fordi det er den gruppering, vi selv tilhører, og den problematik, vi selv står i).

Hele denne kamp udspiller sig imidlertid ikke blot $\gg$ i offentligheden«, den er knyttet til alle de forskellige institutioner, som varetager den ideologiske formidling. Gramscis begreb for etableringen og opretholdelsen af konsensus i en bestemt klassekonstellations interesse er hegemoni. Forudsætningen for opretholdelse af konsensus er, at en bestemt orientering, et bestemt udviklingsperspektiv, en bestemt sammenfatning af indbyrdes forskellige erfaringshorisonter bliver herskende, at det lykkes, igennem de intellektuelles aktivitet, at oprette og opretholde ideologisk hegemoni, overherredømme. For bevidsthedshistorien er det således opgaven at analysere også disse processer, som ikke kan reduceres til de af livsforholdene fremvoksende opfattelser, men netop indbefatter sammenføjningerne, tolkningerne af de forskelligartede baggrunde $\mathrm{i}$ et falles perspektiv. Og disse processer forløber som sagt ikke blot $i$ en ideologisk debat $i$ avisernes kronikker. Der er tale om en højt institutionaliseret sammenhæng. Et eksemplarisk tilfælde kan studeres i den tidlige efterkrigstid, nemlig Heretica-gruppens virksomhed, som efterhånden indbefattede dele af højskolerne, ikke mindst forlagsvæsenet, igennem Knud W. Jensens $k \phi b$ af aktiemajoriteten i Gyldendal og indsættelse af Wivel som direkt $\varnothing r$, derigennem (og igennem selve tidsskriftet) det københavnske kulturmiljø og formentlig, særlig via Martin A. Hansen, en del af seminarieverdenen. Men her er det vigtigt ikke at forfalde til en type af historieskrivning, der kun betragter de institutionelle sammenhænge: ideologisk hegemoni kan aldrig skabes blot gennem, $\emptyset$ konomisk eller politisk formidlet, herred $\emptyset \mathrm{mme}$ over de institutionelle forhold, forudsætningen er til enhver tid udviklingen af ideologiske formationer, der er $\mathrm{i}$ stand til at indoptage de forskellige sociale grupperingers erfaringer. Det er samspillet mellem institutioner og ideologiske formationer, der er af- 
gørende og dermed emne for en bevidsthedshistorisk analyse sammen med realgrundlaget for de forskellige erfaringshorisonter, hvis sammenfatning er forudsætningen for ideologisk hegemoni.

Når det gælder opkomsten af nye sammenfatninger, af et nyt ideologisk hegemoni, er det derfor opgaven at analysere nye sociale omstzndigheder og betingelserne for et brud med det hidtidige ideologiske hegemoni. Og denne analyse indbefatter ikke blot en ny klasses opkomst og livsbetingelser, men også forandringerne $i$ de hidtidige sociale konstellationer. En historisk situation, hvor bestemte klasseinteresser igennem ideologisk hegemoni opretholder sit herredømme, dvs. opretholder forskelligtartede klasser og sociale grupperingers konsensus på sine egne præmisser, kalder Gramsci en historisk blok. Med dette begreb er altså opgaven for den bevidsthedshistoriske analyse, for så vidt angår den overordnede politisk-ideologiske analyse, at studere udviklingen fra den ene til den anden historiske blok, at analysere, hvordan det for en tid lykkes at etablere hegemoni, hvordan brydningerne latent og siden manifest figurerer sig, og, for så vidt angår den historiske dynamik på dette område, at studere, hvordan et nyt politisk-ideologisk hegemoni etableres. Og dette studium indbefatter de intellektuelles sociale situation, deres rekrutteringsbaggrund, de institutionelle sammenhænge, hvori de uddannes og udfolder sig, og ikke mindst den komplicerede ideologiske brydningsproces, hvorigennem de forskelligartede sociale erfaringer sammenfattes til et fælles perspektiv. Dette og de umiddelbare $\emptyset$ konomisk-socialt betingede livssammenhæng er det virkelige historiske indhold $i$, hvad Negt og Kluge kalder brydningen mellem proletarisk og borgerlig offentlighed, det er denne brydning Horkheimer og Adorno under og efter krigen ikke kunne finde i den historiske realitet på grund af kombinationen af fascisme, stalinisme og amerikansk kulturindustri, og det er dette perspektiv, der hos Habermas erstattes af den kritiske intelligensias fors $\emptyset \mathrm{g}$ på at genetablere en "borgerlig « offentlighed på nye historiske betingelser (fraværet af materiel nød som historisk nødvendighed). Det vil ikke sige, at disse eksempler på refleksion over den historiske situation og de 
intellektuelles rolle deri er fuldstændig ugyldige, men det vil sige, at deres indsigter og intentioner for at blive historisk adækvate må gennemgå en fornyet refleksionsproces, der som grundlag må indoptage den historiske realsammenhæng, som også er politisk i sin karakter, og som er præget af uensartetheden af den sociale realitet. Uden disse momenter vil historieanalysen bygge systemer $i$ stedet for at bidrage til opbygningen af grundlaget for et anderledes ideologisk hegemoni, en anden historisk blok. Og det vil også sige, at uden dette perspektiv vil de kritiske intellektuelles historiske perspektiv blive blokeret.

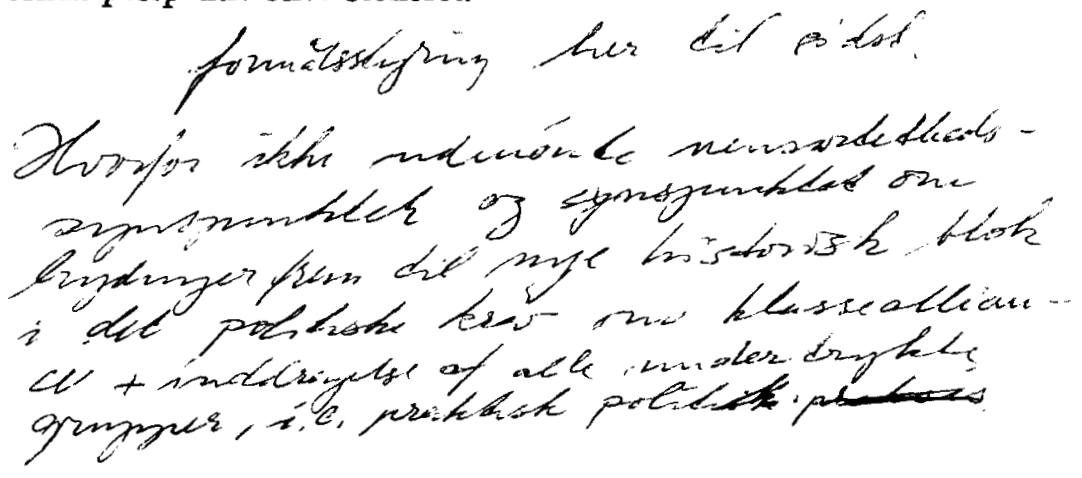

